\title{
ELECTORAL SECURITY AND VOTER-TURNOUT IN THE 2019 GUBERNATORIAL ELECTION IN ABIA STATE: INTERROGATING THE NARRATIVES
}

\author{
Uche Eme-Uche $^{1 \star}$, Elechi Felix $\mathrm{Aja}^{2}$ and Chigozie Okonkwo ${ }^{3}$ \\ ${ }^{1}$ Dr, Evangel University, Akaeze, Ebonyi State, Nigeria, uchemeuche@yahoo.com \\ ${ }^{2}$ Dr, Ebonyi State University, Abakaliki, Ebonyi State, Nigeria, elechifeze2007@gmail.com \\ ${ }^{3}$ Research Fellow, University of Nigeria, Nsukka, Nigeria, chigozie.okonkwo@unn.edu.ng \\ ${ }^{*}$ Correspondent Author
}

\begin{abstract}
Electoral security has serious implications on the survival of democracies, because security is a significant part of an election management process as it influences the level of political participation among the electorates, either during campaign rallies, and coming out to vote on election days. Voter turnout is seen as an important indicator of the state of health of any democracy, old or new, consolidated or in transition. Apart from this, voting is the most important form of political participation especially on Election Day. In Nigeria, there have also been allegations of complicity by incumbents, politicians and security operatives in facilitating electoral fraud during elections as these have affected the level of political participation in terms of voter turnout. This paper examined the intertwining influence of electoral security and voters' turnout in the 2019 gubernatorial election in Abia State of Nigeria. Anchoring our discourse on the theory of the postcolonial state which sees the Nigerian state as privatized and used only as an instrument for primitive accumulation, with data drawn from both primary and secondary sources, and a qualitative descriptive method of analysis, findings revealed that; voter were inaccurate as this was manipulated to favour the incumbent. Also, there was a low turnout of voters during the 2019 gubernatorial election in Abia state as a result of massive deployment of political thugs and coercive instrument of the state (security agents) with the clear intention of rigging the election. This move created fear among the voters who felt that the whole electoral process was flawed. The paper recommends amongst others that; there is need to carry out electoral reforms for effective guarantee of security of the electoral process as this will in turn encourage high voters' turnout in subsequent elections in Abia State.
\end{abstract}

Keywords: Electoral security, electoral violence, post-colonial state, voter register, voter- turnout,

\section{INTRODUCTION}

Electoral security guarantees and enhances the credibility of not only the electoral process, but has serious positive implications for democratic consolidation of any polity. On the other hand, absence of electoral security portends danger to the whole democratic process. As Kerry (2015) stated, "A free, fair and peaceful presidential election does not guarantee a successful democracy, but it is one of the most important measuring sticks for progress in any developing nation". Electoral Security which is guaranteed through the proper enactment and implementation of the Electoral Act helps to increase voters' turnout during elections 
and reduces to a reasonable extent the challenges of threats, bitterness, lawlessness, killing and destruction of lives and properties that have become inherent in most elections in Nigeria (Jega, 2015). Electoral security has serious implications on the survival of democracies, because security is a significant part of an election management process as it influences the level of political participation among the electorates, either during campaign rallies, and coming out to vote on election days. Voter turnout is seen as an important indicator of the state of health of any democracy, old or new, consolidated or in transition which can be guaranteed under a secure atmosphere. Apart from this, voter turnout is the most important form of political participation especially on Election Day. In Nigeria, there have also been allegations of complicity by incumbents, politicians and security operatives in facilitating electoral fraud in past and current elections as these have affected the level of political participation in terms of voters' turnout.

Elections in Nigeria continue to witness growing disappointments and apprehension due to the inability of the government through the many electoral management bodies that have been constituted over the years, to conduct peaceful, free and fair, open elections whose results are widely accepted and respected across the country (Igbuzor, 2010; Osumah \& Aghemelo, 2010; Ekweremadu, 2011). All the elections that have been conducted in Nigeria since independence have generated bitter controversies and grievances on a national scale because of the twin problems of mass violence and fraud that have become central elements of the electoral process in the country (Gberie, 2011; Oni, Chidozie \& Agbude, 2013). Despite the marked improvement in the conduct of the 2011 and 2015 general elections, the process was not free from malpractices and violence (National Democratic Institute, 2012).

With the conduct of 2015 general election which saw the change of government from the then ruling People Democratic Party (PDP) to an opposition party, the All Progressive Congress (APC), one had expected to see an improvement on the gains made in 2015 reflected in the 2019 general elections, in terms of transparency, adherence to democratic ethos and reduction of electoral violence. Rather the reverse was the case as there were cases of electoral malpractices ranging from kidnapping, killings, destructions of electoral materials, vote-buying, wilful cancellation of elections, and wrongful declaration of election as inconclusive to outright involvement of the military in aiding and abetting electoral crime both at the presidential election and the gubernatorial elections, especially in Abia State. Deriving from the brief exposition above, this paper examined the intertwining influence of electoral security and voters' turnout in the 2019 gubernatorial election in Abia State.

The paper employed an exploratory research design and adopted qualitative method of data collection and a qualitative descriptive method of analysis. The paper is divided into six sections namely; introduction, theoretical framework, review of related literature, electoral security and voters turnout in the 2019 gubernatorial election in Abia sate, reasons for the low voters turnout in the 2019 gubernatorial election in Abia state, and conclusion and recommendations.

\section{THEORETICAL FRAMEWORK}

Our discourse in this paper is anchored on the theory of the post-colonial state as propounded by Hamza Alavi (1979), Ake (1975, 2000), Ekekwe (1986) and Ihonvbere (1989, 2000). Alavi (1979) in his analysis of the states of Pakistan and Bangladesh provided an important starting point for analysis of the state in postcolonial societies. Alavi premised his argument on the historical specificity of post-colonial societies, which he noted as; a specificity which arises from structural changes brought about by the colonial experience and alignment of classes and by the superstructures of political and administrative institutions which were established in that context, and secondly from radical re-alignments of class forces which have been brought about in the post-colonial situation. In general, the propositions developed by Alavi in his analysis of Pakistan and Bangladesh prove most illuminating when applied to the Nigerian experience. Alavi argued further that the postcolonial state is over-developed in relation to the economic structure over which it presides in the sense that it is characterized by a strong relatively autonomous, military bureaucratic oligarchy.

The first two decades of political independence in Africa witnessed the containment of the robust enthusiasm for freedom that had informed the popular challenges to colonial domination. The new power elite simply Africanized or indigenized the exploitative, repressive, and arrogant appropriation and deployment of power that had been the tradition of the colonial state. This often required the containment of the media, the marginalization of rural areas, the harassment of political opponents, and the subversion of the constitution. Within two decades of political independence therefore, the continent was littered with coups and countercoups, civil and inter-state wars, ethnic violence, agitations for autonomy, alienation from the state and its custodians, and the withdrawal of support for public policies. Good governance was thrown over-board and leaders busied themselves with the construction of dubious ideologies, personality cults and looting their respective treasuries. 
The postcolonial state was privatized and used only as an instrument for rapid primitive accumulation and its instruments of coercion were frequently deployed to settle private disagreements and the control of power by political despots. Coupled with economic mismanagement, rabid corruption, irresponsible political behaviour and squandermania, the near abandonment of the state by its very custodians weakened it and made it largely irrelevant to the daily lives of the people. The state was now seen and treated as enemy by the people, a force that was to be avoided, cheated, attacked, and subverted as opportunity permitted. Such a state had no room for the rule of law, social justice, human rights, and constitutionalism. Ihonvbere (1989) pointed out that Nigerian elite have become obsessed with the "power project" not for promoting growth and development but for inflicting pain and misery on the peoples of Nigeria. This project is also a diabolical strategy for subverting the goals of nationhood and recycling the inherited distortions and disarticulations of the Nigerian social formation.

The theory of the postcolonial state sees the Nigerian state as being privatized and used only as an instrument for primitive accumulation and perpetuation of self-rule and civilian dictatorship. The low voters turnout during the gubernatorial election could be seen in how the struggle for power among the elite has result to the abandonment of democratic rules and the usurpation of the popular will to satisfy entrenched interests of the few with the help of political thugs in connivance with the coercive arm of the state to unleash mayhem on the very people they are supposed to protect.

\section{REVIEW OF RELATED LITERATURE}

\subsection{Election}

Election is the most foundational element of modern-day representative democracy. It is a means through which the electorates at periodic times choose their representatives into different positions of governance; it refers to institutionalized procedures for recruiting political office holders by the electorates of a country or groups. Thus, how a state arranges and conducts its elections is emblematic of the level of political development of that particular state. The institutional medium provided by elections also allows different interest groups within a state to stake and resolve their claims to power through peaceful means. It, therefore, determines the manner and methods by which changes in the social order may be brought about in a democratic society. Consequently, the procedures adopted must be recognised by law in order to give it legitimacy, thus, it is necessary that in conducting such procedures it must be acceptable to those who participate, by being seen as fair and credible. These processes must take place under conditions that are peaceful and non- intimidating such that participation is without let or hindrance (Igini, 2013; Katuka, Elechi \& Ohazuruike, 2019).

Heywood (1997, p.211) noted that; election is a device for filling an office or post through choices made by a designated body of people "the electorate". This definition is in accord with the opinion advanced by the Nigeria Court of Appeal as "the process of choosing by popular votes a candidate for political office in a democratic system of government". Heywood (1997) further submits that election aims to perform specific functions in any democratic setting. These include political recruitment, representation, making government, influencing policy, building legitimacy, shaping public opinion and helping to strengthen the elite. Given these essential functions of election in contemporary democratic states, it is logical to argue that election is not just an Election Day activity, though a crucial component. Rather, election encompasses political activities before, during and after the election days. This explains why the phenomenon of election in modern democracy is an institution rather than a mere terminal composition of an electoral committee (Ojo \& Ademowo, 2015).

Kambudzi (2008 cited in Ugbudian, 2015) postulated that through the mechanism of election, citizens seek to improve their lives by listening to views and options offered by political candidates on vital issues of national life and making weighted choices among them. Citizens use elections to keep government up to task of providing for basic societal needs and pursuing unrelenting improvement of the country. This is how properly conducted elections play a role as a development asset in any given country (Ugbudian, 2015; Katuka, Elechi \& Ohazuruike, 2019).

\subsection{Security}

In its broad sense, security has been defined as an atmosphere of guaranteed protection, and the condition of feeling happy and safe from danger and harm. Security gives meaning to human existence in time perspective. Hence, Nwolise (2009) cited in (Ojo \& Ademowo, 2015) submits that the security of a person, identity group, nation, or the world is not only a sacred and strategic value, it is the utmost value. This is because unless one can be assured of his physical security or safety, everything else will be meaningless.

Security is indispensable to the conduct of free, fair and credible elections. From the provision of basic 
security to voters at political party rallies, campaigns, voting, to ensuring that election results are announced and result forms are protected, the whole electoral process is circumscribed by security considerations.

\subsection{Electoral Security}

Electoral security implies protection or safety from any form of impediment that can distort the conduct of credible election within the context of acceptable democratic tradition and culture (Ojo \& Ademowo, 2015). Fisher (2002) quoted in Albert (2007); defines electoral security as "the process of protecting electoral stakeholders such as voters, candidates, pool workers, media, and observers; electoral information such as vote results, registration data, and campaign material; electoral facilities such as polling stations and counting centres; and electoral events such as camping rallies against death, damage, or destruction".

Thus, electoral security is all about securing the holistic integrity of the electoral process, especially now that elections are increasingly seen as a key component of peace-building process and a cornerstone of dynamic social interaction. Hence, electoral security must address protection from the physical, psychological and structural threats against the electorate and the citizenry at large, without undue consideration for party affiliation, ethnic sentiment, historical antecedent, religious divide, or any other form of social differences. The bottom line is that a political environment that is free from threat to electoral security ensures that political parties and their candidates win in the scheme of power without jeopardizing the safety of rivals and the citizenry, and without distorting the sanctity of the electoral process (Ojo \& Ademowo, 2015; Katuka, Elechi \& Ohazuruike, 2019).

The significance of electoral security cannot, therefore, be overemphasized. Electoral security is crucial for creating the proper environment; electoral staff require to carry out their duties; for voters to freely and safely go to their polling units to vote; for candidates and political parties to organize rallies and campaigns; and for other numerous stakeholders to discharge their responsibilities under the Constitution and the Electoral Act. In planning, coordination and deployment matters pertaining to electoral processes, well-coordinated security is a fundamental requirement for success. Adequate security ensures the free movement of electoral staff, voters, candidates, observers and other stakeholders on Election Day, which, in turn adds to the credibility of the electoral process. Similarly, adequate security is an important pre-condition for the deployment of valuable electoral assets and sensitive materials to registration and polling sites. Adequate security increases the level of participation of political parties, candidates and voters in an election. It also enables a more objective coverage of events by the media and easier circulation of voters' education, message and materials (Jega, 2012).

In view of the scale of general elections, the number of people involved, election materials that need to be moved, difficulty of the terrain to be traversed, as well as the physical locations that need to be protected, such an operation is complex. It represents logistics and planning challenge that require a wide range of stakeholders, processes, locations, and issues in time and space (Jega, 2012). Whether we are talking of electoral staff, voters, or other stakeholders such as candidates and their agents, parties, civil society organizations, domestic and international observer groups and security agencies themselves, security is critical in the protection of electoral personnel, locations and processes; in ensuring that voters exercise their civic duties without fear or hindrance; in creating a level playing field for all political parties and candidates to canvass for support; in protecting domestic and foreign observers in discharging their duties and obligations, and in maintaining the overall integrity of the democratic and electoral processes.

\subsection{Voter -Turnout}

A voter is a citizen who is 18 years old and above, and is duly registered to elect political office holders. In effect anyone who can exercise the right to vote is a voter. However, not all voters can be voted for. Voterturnout is the absolute number of people voting in an election or is the share of the population that has cast its vote in a general election. Voter turnout is one measure of citizen participation in politics. It is usually expressed as the percentage of voters who cast a vote ("turnout") at an election. This total number of voters includes those who cast blank or invalid votes, as they still participate. A voter is a person who has a right to participate in an election as an elector. Voter-turnout is the most important indicator of popular participation in an election and, by extension, of the legitimacy of government.

Apart from its qualification as the most important form of political participation, voter turnout has also been seen as an important indicator of the state of health of any democracy, old or new, consolidated or in transition, where a high turnout is usually associated with a healthy democracy and a low one with an unhealthy one (Kuenzi \& Lambright, 2007; Freitag 2010; Omotola \& Aiyedogbon, 2012).

Voter-turnout has been identified in the extant literature as one of the core ways of measuring the level of participation in any election (Blais \& Dobrzynska, 1998). Voter- turnout is usually measured as a percentage 
of registered voters who vote. The assumption is that the higher the level of voter- turnout, the higher the level of participation and, by extension, the greater the democratic quality of the election (Lindberg, 2004, 2006; Altman \& Perez-Linan, 2002, Lijphart 1997). As Bratton (1999, p 570) bluntly puts it, 'voter registration was revealed as the single most important determinant not only of a citizen's behaviour but also of overall participation, outweighing any other institutional, cultural, or social consideration'. Other major studies support the claim that declining voter turnout is a reflection of the poverty of democracy (Berg-Schlosser \& Kersting 2003; Cornwall 2002; Young 2000; Omotola \& Aiyedogbon, 2012).

\subsection{Election and Security: A Theoretical Nexus}

Election as one of the most foundational element of modern day representative democracy is important because it most cases, election ushers in democracy, while periodic elections sustain it. Consequently, the procedures adopted in election must be recognised by law in order to give it legitimacy, and it is necessary that in conducting such procedures it must be acceptable to those who participate, by being seen as fair and credible. These processes must take place under conditions that are peaceful and non- intimidating such that participation is without let or hindrance.

Electoral security is key to the integrity of electorates, electoral personnel, election materials, contestants, election monitors/ observers and other stakeholders who participate in the electoral process. Two broad categories may, therefore, be used as the focus of security requirements for election purposes, namely, the security of participants and the security of materials. Participants in the election process include, election managers/personnel, contestants, media practitioners, observers and voters. While materials used for elections are sensitive and non-sensitive materials. Non sensitive materials include ballot boxes, cubicles and other materials required for elections, whereas sensitive materials include ballot papers, result forms and envelopes with official legal marks or bearing. Where electronic processes are used to facilitate elections, the fidelity of the technology, its robustness against failure and deliberate distortions may also constitute part of election security.

\section{Electoral Security and Voters Turnout in the 2019 Gubernatorial Election in Abia Sate}

States such as Abia, Enugu and Ebonyi witnessed the lowest turnout, with less than 30 per cent of their registered voters marking the ballot. This is in stark contrast to 1999 when 70 per cent of all registered voters turned out to usher in Nigeria's new democracy. However, the March 2019 gubernatorial elections were the opposite. There was an extreme case of low voter-turnout. In Abia, while 1,349,134 million registered, only 442,538 thousand were accredited (Sahara Reporters, 2019).

Despite the presence of security men mounting road blocks and checks across the country, there were reported cases of political thugs moving freely around polling units and disrupting the election process. Some electoral officials and voters were assaulted in the process. There were several reports and live feeds of electoral violence from all over the country. Party thugs and hoodlums had a field day invading voting centres to snatch polling materials, destroy voting materials, harass, molest and intimidate voters and, in some instances, INEC officials. Suspected political thugs, accompanied by security operatives particularly persons in the uniforms of officers and men of the Nigerian Army, hijacked and destroyed materials, interfered with the voting processes, hindered voting and or prevented the counting of votes at some voting centres, chased away some party agents and observers from polling units and collation centres.

In Abia State, armed thugs invaded and unleashed violence at Ekiri Elu Central School, Aram Umuahia, forcing the INEC ad-hoc staff to abandon the election and run into private residences for safety. There were credible reports of harassment, intimidation and killings which called for serious security concern and put the credibility of the entire process in issue. The specific incidents noted here are by no means exhaustive. Governor Okezie Ikpeazu of the Peoples Democratic Party, PDP, has been declared the winner of the 2019 gubernatorial election in Abia State (NBA, 2019).

Ikpeazu polled the total number of 261,127 to defeat Uche Ogah of the All Progressives Congress, APC, and Alex Otti of the All Progressives Grand Alliance, APGA. He was declared winner by the INEC Returning Officer, Prof. Benjamin Ozumba 
Figure 1. INEC Staff Waiting for Voters to Turnout

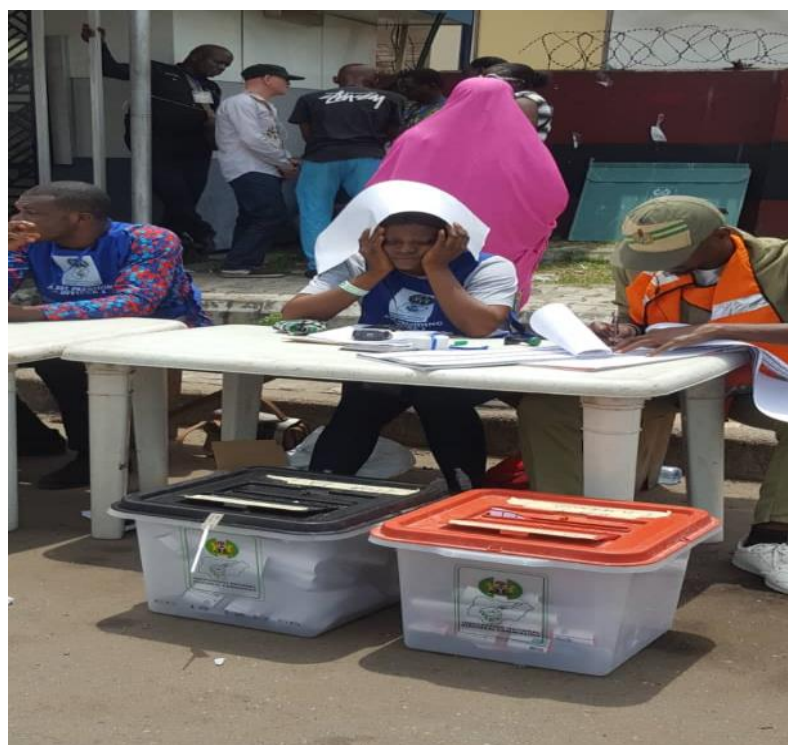

Low voter- turnout was witnessed in most parts of the polling units visited in Abia State as depicted by the picture above. The News Agency of Nigeria (NAN) correspondents who monitored the elections in Abia State reported that few voters were seen trickling to their various polling centres as at 10a.m. In Aba, Abia, voting in Osisioma local government and Aba South local governments commenced at about 8: 00 am on Saturday as INEC ad-hoc staff had deployed to work arrived as early as 7 a.m. However, in some centres, INEC staff was ready waiting for voters to come and perform their civic responsibilities.

At Ngwa High school, although the electoral staff were ready, elections were yet to commence because there were no voters available. Only one party agent working for the All Progressives Grand alliance (APGA) was also around to witness the commencement of voting. Mr Evans Evuru, an APGA party agent who spoke to NAN at Ngwa High School centre said he reached the centre by 7: 00 am while INEC staff came by 7:30 am.

He said voting was yet to start at the centre by 8: 00 am because voters were not around to vote at commencement time.

At Constitution Crescent Primary school Ward 12, Units 5 to 9, in Aba South LGA, elections had begun by 8:10 am. No security agent was sited at the centre. Meanwhile, soldiers were seen at strategic places at Aba manning road checkpoints. Some personnel of the Customs and Excise and Policemen were on guard at the venue which also served as a collation centre for Aba South LGA (News Agency of Nigeria, 2019).

Meanwhile, the APC calls for cancellation of the March 9 gubernatorial election in Abia state. The party cited alleged plethora of electoral anomalies including cases of snatching of ballot boxes, non use of Card Readers, thuggery and intimidation witnessed in so many LGAs in the state as its reason for doing so. It also claimed that the manipulation of voters at polling units by some staff of the Independent National Electoral Commission (INEC) was also very high, adding it should not be allowed to stand.

Addressing journalists in a press conference in Aba, the spokesperson of APC in the state, Benedict Godson, whose view point, called for total cancellation of all results and the immediate sack of Joseph lloh, the state Resident Electoral Commissioner of INEC. We beg to quote him in extenso:

The election in Abia yesterday (Saturday) was a fraud. It is not worthy to be recorded as election. Abia APC calls for total cancellation of the Governorship Election in Abia because there was no proper voting except if INEC is saying now that the criminality we witnessed yesterday is the definition of election in Nigeria. What took place on the 9th of March 2019 in many LGAs, Wards and Polling Units in our state was an organised crime. It was never an election. The intimidation of our agents, our candidates, supporters and even many innocent Abia people who only came out to effect the change we all are yearning for was what took place. The REC, Dr. Joseph lloh is a PDP member. Before the election, we kept saying we don't trust him and the then Police Commissioner who was only removed noon Friday and the new person cannot effect much changes in security. In almost all the Wards in Osisioma South and Osisioma North State Constituencies, the PDP thugs snatched ballot boxes, beat up our Agents and intimidated everyone who tried to express a different opinion. Our candidate in Osisioma South State Constituency, Hon. Chima Oriaku was beaten black and blue by the PDP thugs and was hospitalized. Information we are getting now is that his life is still under 
threat and we are doing our best to ensure nothing goes wrong with him. Innocent Abia people who came out at Osisioma were chased away in places they discovered were APC strongholds (Citied in Eze, 2019).

Mr Godson added that ...

in many Wards, Card Readers were abandoned for manual voting as INEC staff were seen directing voters to vote without due process; "they just thumb-printed recklessly without due process. From Obingwa, Osisioma, Ohafia, Ukwa East and West down to Ugwunagbo and Isiala Ngwa South and North there was nothing like elections. Materials were missing and incomplete in so many places

Similarly, the Deputy State Chairman of the All Progressives Grand Alliance (APGA), Felix Nkoro, has called for the cancellation of the entire election in Osisioma LGA describing it as a huge fraud. According to him:

Before the arrival of other Party Agents, INEC in collusion with the PDP had started making use of electoral materials. At St. Michaels in Osisioma LGA, the APC Agent was beaten badly for questioning the wrong doings he witnessed there. In Abayi Umuocham Girls' Secondary School, PDP thugs and security agencies pushed our agents out and manipulated votes. In Ariaria and Okpulo-Umuobu it was the same story of intimidation and harassment. The Card Readers were not deployed. Accreditation of voters was done manually. Some persons voted up to seven times for the PDP. We hereby reject the election in Osisioma and we call for its cancellation (Eze, 2019).

There was an increase in the number of invalid ballots compared to 2015 as rates reported by EU observers in some LGAs. This raises questions about ballots being selectively declared invalid for political advantage. Also, a well-known local journalist/activist who criticised the Governor was arrested after a live radio programme. The journalist was first charged under the Cybercrimes Act for insulting online and "cyberstalking" the Governor in 2018. On March 7th, the charge was changed to violation of Abia's state Anti-Terrorism Legislation (EU Election Observation Mission Nigeria General Elections, 2019)

During the 2019 general elections, there were reports of alleged hijack of Ballot Papers at Ihechiowa in Aro Chukwu Council Area, World Bank Primary School in Umuahia. Also, the governorship candidate of All Progressives Grand Alliance in Abia State, Dr. Alex Otti called for the cancellation of the Governorship and State House of Assembly elections in the state in poll's result in 15 of the 17 LGAs of the State, alleging that the elections were marred by massive irregularities such as; armed thugs suspected to be loyal to PDP who allegedly invaded polling units, shooting sporadically and snatched Ballot Boxes.

Despite the challenges that occurred which led to the low turnout of voters during the Gubernatorial Election in Abia State, the incumbent Okezie Ikpeazu was still declared the winner with the following scores and margin as contained in the table below:

Table 1. Result of 2019 Abia State Governorship Election

\begin{tabular}{|l|l|l|l|l|l|}
\hline S/N & NAME OF CANDIDATE & GENDER & PARTY & VOTES RECEIVED & REMARK \\
\hline 1 & Emeka Uwakolam & Male & A & 43 & \\
\hline 2 & Ubani Vincent Anthony & Male & AAC & 254 & \\
\hline 3 & Opara Alphonsius Obinna & Male & ACD & 166 & \\
\hline 4 & Obinna Kelenna & Male & ADC & 333 & \\
\hline 5 & Okey Okoro Udo & Male & ADP & 522 & \\
\hline 6 & Igwo Nnanna Okpan & Male & AGA & 293 & \\
\hline 7 & Onuoha Uko Igwe & Male & AGAP & 247 & \\
\hline 8 & Ulunwa Utokannandu Morgan & Male & ANP & 289 & \\
\hline 9 & Ogah Uchechukwu Samson & Male & APC & 99,574 & \\
\hline 10 & Alex Otti & Male & APGA & 64,366 & \\
\hline 11 & Umeh Charles Okezi & Male & APP & 138 & \\
\hline
\end{tabular}


IJASOS- International E-Journal of Advances in Social Sciences, Vol. VI, Issue 16, April 2020

\begin{tabular}{|c|c|c|c|c|c|}
\hline 12 & Chijioke Owanta & Male & ASD & 35 & \\
\hline 13 & Michael Imojo Ndu & Male & AUN & 29 & \\
\hline 14 & $\begin{array}{l}\text { Chinwuba Queen Edith } \\
\text { Asikaralinoun }\end{array}$ & Male & CAP & 21 & \\
\hline 15 & Obasi Heavens Ugochukwu & Male & DA & 14 & \\
\hline 16 & Paul Chinedu Emmanuel & Male & FRESH & 22 & \\
\hline 17 & Annyalewachi Nwaozuru & Male & GPN & 33 & \\
\hline 18 & Gilbert Chikezie Chris & Male & ID & 38 & \\
\hline 19 & Charles Okechukwu Okereke & Male & JMPP & 40 & \\
\hline 20 & Benson Chibunna Onyekachi & Male & $\mathrm{KP}$ & 102 & \\
\hline 21 & Igara Ceekay Kalu & Male & LP & 520 & \\
\hline 22 & Udeagha Rose Uzoaru & Female & MPN & 124 & \\
\hline 23 & Madu Anthony Chukwuonye & Male & PDC & 442 & \\
\hline 24 & Okezie Victor Ikpeazu & Male & PDP & 261,127 & $\begin{array}{l}\text { Declared } \\
\text { Elected }\end{array}$ \\
\hline 25 & Okoronkwo Fortunes Paul & Male & PPC & 1,044 & \\
\hline 26 & Chukwudi Nnabugwu & Male & PPN & 624 & \\
\hline 27 & Awa Ezekiel Anya & Male & PT & 53 & \\
\hline 28 & Ahaiwe Udochukwu Elvis & Male & $\mathrm{RP}$ & 89 & \\
\hline 29 & Hon. (Mrs) Blessing Nwagba & Female & SDP & 2,191 & \\
\hline 30 & Francis Onugu Ukwu & Male & UPP & 151 & \\
\hline 31 & Nkoro Joseph Ngozi & Male & YPP & 100 & \\
\hline 32 & Orji Kingsley & Male & ZLP & 291 & \\
\hline
\end{tabular}

Source: Independent National Electoral Commission (INEC): Abia State Governorship

Election, 2019, Results of Election

\section{REASONS FOR THE LOW VOTER-TURNOUT IN THE 2019 GUBERNATORIAL ELECTION IN ABIA STATE}

\subsection{Vote Rigging}

Voting was delayed in some cities due to the late arrival of materials, according to election monitors, and there were allegations of vote rigging in Abia South. Some voters also stayed away from Saturday's exercise after the February 23 polls were marred by violence and armed thugs burned and snatched ballot boxes. Chinedu Obiora, a businessman told Al Jazeera that:

I did not vote because last two Saturdays, the violence in my polling unit scared me away. After voting [thugs] came and burned our result sheets. I don't trust the system to conduct the elections and I couldn't have risked my life as a result of today's exercise, I stayed home with my family monitoring on TV.There appeared to be far fewer people taking part in Saturday's governorship and state assembly polls compared 
with the presidential and National Assembly elections when electoral officers in some polling areas were overwhelmed with large numbers of voters.

Chioma Agwuegbo, an Election Observer told Al Jazeera on $29^{\text {th }}$ March, 2019, that:

The turnout of voters in the five polling units we visited today was abysmal, at some polling units, the election officials especially the Party Agents, were more than the voters. Voters, especially young people, feel betrayed by the electoral commission. They believe that their votes did not count in the elections from February 23, and don't trust the system enough to come out again.

\subsection{Electoral Violence}

In the lead up to the elections, three INEC offices were set alight in Isiala Ngwa South Local Government Area of Abia State, This incident led to loss and damage of sensitive materials (https://www.inecnigeria.org/resources/press-release/). Also, armed thugs invaded and unleashed violence at Ekiri Elu Central School, Aram Umuahia, forcing the INEC ad-hoc Staff to abandon the election and run into private residences for safety.

\subsection{Enforcement of security}

The laudable provisions of the Electoral Act on securing the electoral process suffered some setbacks particularly with respect to the enforcement of the provisions of the Electoral Act. The Security Agencies whose primary responsibility is the enforcement and maintenance of law and order in every circumstance shied away from same when it comes to election matters. In Abia State like many other States of the Federation, the Police complained that they do not have instructions from the Independent National Electoral Commission (INEC) to arrest offenders on Election Day. The provision of Section 59 of the Electoral Act 2010 (as amended) which empowers the Presiding Officer to order the police to arrest persons impersonating at election is misinterpreted to mean that Police cannot arrest election offenders unless ordered by INEC. The Nigerian Army is by law not allowed to intervene in civil matters, election being one. The Nigerian Army is therefore not deployed to maintain peace at polling units. Military personnel, if they must be used, are strategically deployed to forestall violence and do not have power to deal with electoral offenders (Bawa, 2013). It was a different game all together during the Governorship Election in 2019 as the Army was accused of meddling in the electoral process through aiding and abetting electoral crime.

\subsection{Lack of Fairness and Transparency in the Electoral Process}

This has been identified as the major cause of pre-election violence in Nigeria. A situation where electoral processes at any stage is shrouded in secrecy or the parties that fielded in candidates for elections are not carried along as expected could be an invitation to political violence. For instance, it has been observed that the ruling party takes undue advantage of their privileged position to select their party members and supporters to serve as INEC adhoc staff. The implication of the foregoing is that those adhoc personnel strive strenuously to scuttle the whole electoral processes in favour of their party. Incidentally, other political parties that feel threatened that such irregularities could mar their electoral success always mobilize their army of supporters and thugs to protest the perceived injustices. This situation in most instances nosedives to political violence, as witnessed during the 2019 Governorship Election in Abia State.

\subsection{Non Credibility of the Electoral Body}

A situation when the electoral umpire is perceived either through its actions or inactions to have reneged from its constitutional duty of ensuring impartial administration of the electoral process has ridiculed the integrity of the government and spell doom for the country. INEC was seen to be romancing with the ruling party (PDP) in Abia State during the governorship election and this led to the manipulation of election results in their favour to the exclusion other parties or contestants. This action by INEC to a large extent led to the low turnout of voters as majority of the voters felt there was no need to cast their vote when the electoral umpire that is supposed to impartial and neutral was seen to be towing the line of the ruling party.

\subsection{Ineffectiveness of Law Enforcement Agencies}

The lacklustre disposition of Nigerian law enforcement agencies is a major contributory factor to turbulent elections. It is no longer news that Nigeria is acknowledged to have best legal frameworks but her predicament appears majorly to be non-enforcement or poor enforcement of those rules. Essentially, the Electoral Act designed for the purpose of guiding the conduct of everyone before, during and after elections; it is rather unfortunate that these rules are oftentimes flouted with impunity even at the watchful eyes of the security agents. In extreme cases like the 2019 general elections, especially in Abia State, evidence abound that the police and other security agencies aided and abetted the rigging of elections as well as intimidated 
voters which implies that the institution set up to protect the electoral process became a cog in the wheel of progress of the process.

\subsection{Inordinate Political Ambition}

Politics in Nigeria has been perceived as a gold mine where any aspiring politician should venture to satisfy his quest for wealth. This has been unarguably responsible for the huge number of persons who go into politics in the country. Thus, in order to achieve their inordinate ambitions, these politicians go extra miles to truncate the rules of the game so as to succeed at all cost. This explains the deployment of armed thugs as ready instruments to wreck havoc on perceived political opponents before, during and after elections. This in turn influence the low voter- turnout in Abia State as the gladiators were ready for war through the arming and giving security cover to their thugs by the security agencies, who were let loose on the armless voters whose only crime was to come out and perform one of their civic duties.

\subsection{Corruption}

A large proportion of Nigerian politicians are desperate to win elections; they do not adhere to rules and regulations that guide to the conduct of any government business. Also, a good number of the regular staff and adhoc staff of the electoral umpire see their appointments as great opportunity to enrich themselves especially during election periods. They, in most cases, connive with desperate politicians after financial inducements to manipulate election figures in their favour. Monetary inducements determined the winners and losers. 'Secure the bag' rose in ranks at the expense of contesting to serve the people. Bullion vans moved freely on the streets. We saw no wrong in this yet we answer the title- propagators of modern democracy. We helped Nigerians to strip and banish democracy and its principles in the scheme of things. Transactional politics wrestled with ideologies (Ojukwu, Mazi Mbah \& Maduekwe, 2019). This is exactly what played out in the 2019 gubernatorial election in Abia State. Cases abound where adhoc staff on the field sold ballot papers to the highest bidders which were clear cases of electoral irregularities. The outcome of this phenomenon is always a burning anger on the part of the electorates who perceive the result of the elections as not reflecting their choices. This is one of the reason there was a low voter- turnout in Abia State.

\subsection{Unemployment}

Unemployment is seen as the main contributory factors to electoral violence. Politicians have found it expedient to impoverish a large number of youth so that they will become willing tools to unleash mayhem during election periods. Some of the unemployed youths also go into politics with the sole aim to cause confusion since politicians and political system are not after their welfare. Most of the youths who are involved in electoral thuggery are unemployed, frustrated and have become willing tools to the highest bidder. Abia State was not left out the use of thugs to cause mayhem during the 2019 governorship election.

\subsection{Postponement of the Elections}

The postponement of the elections affected votes recorded at the polls on March 9, 2019. It appeared many citizens had lost confidence in the process initially scheduled for March 2.

Their minds were made up (Thisday, Monday, April 8, 2019). Although they can't feign ignorance of conspiracy at collation centres, apathy fuels and prepares the ground for the enthronement of compromise (Ojukwu, Mazi Mbah \& Maduekwe, 2019).

\subsection{Disjointed Information from the Media}

The media is democratically seen as vanguard for holding governments accountable and guarding against the abuse of power. This can be done by raising structures of surveillance to monitor government activities and stem an inherent disposition towards excesses. But in Nigeria especially in this Republic, there are constraints on press media resulting in suppression of information, provision of disjointed and half hazard information and thereby limiting the capacity of individuals to develop a reservoir of political knowledge to assist them in controlling authoritarian rule and participating adequately in political activities. Our media has been subsumed into the elite structure "the big man" syndrome or "upper body structure". This is actively inimical to the survival and deepening of democracy (Awuudu, 2012; cited in Ojukwu, Mazi Mbah \& Maduekwe, 2019).

\subsection{The Incumbency Factor}

Incumbency refers to holders of political office who enjoy certain privileges as a result of the position they occupy and which are not available to other contestants in the electoral contest. These privileges create some electoral margin for the incumbent running for re-election leading to an incumbency abuse factor. In 
Nigeria, and especially during the 2019 Governorship election in Abia, this factor promotes appointment of corrupt and or compromised electoral officers, manipulation of the electoral law and the constitution, manipulation of the electoral tribunals to protest stolen mandates, use of state security forces and apparatus to intimidate opposition parties, denial of access to state owned media houses etc to ensure they regain or elongate their tenure against popular will (Nwanegbo \& Alumona, 2011 cited in Ojukwu, Mazi Mbah \& Maduekwe, 2019).

\subsection{Citizens' Belief that Their Votes will not Count in the 2019 Gubernatorial Election in Abia State}

Majority of the registered voters refused to turn out and vote on the Election Day in Abia State because of the negative belief that votes do not count in the country. This is a result of years of ballot snatching, mutilation of result sheets, multiple voting and other vices that had marred the electoral process. In view of the large-scale manipulation and scuttling of the voting process that ends in the announcement of results that did not reflect the actual votes cast and the yearnings of the people citizens preferred to sit in the comfort of their homes than stand under the scorching heat of the sun to cast a vote that would not count (Mill, 2011).

\subsection{Voter Intimidation}

There were cases of the use of thugs, cultists, criminals. Militants and even government security personnel to intimidate political opponents and voters during the build up to the Gubernatorial elections in Abia State which had been a trend in Nigerian politics. In some cases, the thugs snatched the ballot boxes and mutilated votes. Sadly, the security forces in some instance tallied with the government in intimidating voters in favour of the preferred candidate. Hence, even with the presence of security forces, the citizens of Abia State still maintained an attitude of apprehension over the voting process.

In addition to the foregoing, the political space of the country did not offer any iota of hope for the citizen to feel at home with the system. Politics in Nigeria is a serious battle that is orchestrated to dislodge, destroy and defame the opponent. Unlike the developed democracies where politics are issue based and content filled, politics in Nigeria is a struggle for survival. Agu, Okeke, and Idike (2013) cited in Onwuama (2018), expressed that politics in Nigeria is regarded as a dirty game and it is practiced with bitterness, hatred, rancour and other associated evils. The outcome of this is that Nigeria is in vicious cycle of political crises and instability. The spirit of sportsmanship is next to zero and no loser seems to be in concordance with the electoral process (Onwuama, 2018).

\section{CONCLUSION AND RECOMMENDATIONS}

The average Nigerian has been so profoundly frustrated, disappointed and devastated by the crude manifestations of the mechanics of Nigerian electoral politics, so much so that they have become either apathetic and indifferent, or exceedingly cynical or sceptical about election, hence the low turnout of voters during elections. The civic duty of going out to vote in elections had become very dangerous, exposing voters to risks of being assaulted, injured, killed by armed thugs doing the bidding of some politicians, or by some deranged militants and terrorists. If they succeeded in casting their votes unscathed, they watch helplessly as the votes were stolen, or the election results purchased from crooked election and security officials, such that for all practical purposes, their votes don't count. In the circumstances, many citizens withdrew from the electoral process and/or became extremely skeptical about the value and utility of elections.

Voter registers, upon which voting and the computation of voter turnout are predicated, were inaccurate as these were manipulated to favour the incumbent. Also, there was a low turnout of voters during the 2019 gubernatorial election in Abia state as a result of massive deployment of political thugs and coercive instrument of the state (security agents) with the clear intention of rigging the election. This move created fear among the voters who felt that the whole electoral process was flawed.

Deriving from the above, the paper put forth the following recommendations as a way of addressing the electoral challenges so as to improve voter- turnout in elections.

1. The people must take active role in fighting electoral violence in the state and the national level.

2. There should be a total overhaul of the electoral architecture of the Nigerian State.

3. There is an urgent need to pass the amended Electoral Act into Law for subsequent conduct of elections in Nigeria in order to aid and facilitate the transition to electronic collation of results.

4. There is need to carry out electoral reforms for effective guarantee of security of the electoral process as 
this will in turn encourage high voter-turnout in subsequent elections in Abia State in particular and Nigeria in general.

5. There should be a special court created to try election related offences.

6. Corruption cases related to election should be equally handled by the proposed court as the culprits should be forced to face the full wrath of the law.

\section{REFERENCE LIST}

Abah, E. O. \& Nwokwu, P. M. (2015). Political Violence and the Sustenance of Democracy in Nigeria. IOSR Journal of Humanities and Social Science (IOSR-JHSS), 20(11/1), 33-44.

Agu, S. U., Okeke, V. O. \& Idike, A. (2013). Voters Apathy and Revival of Genuine Political Participation in Nigeria. Mediterranean Journal of Social Sciences, 4(3).

Albert, O. I., Marco, D \& Adetula, V. (2007). Perspectives on the 2003 Elections in Nigeria. Abuja: IDASA.

Altman, D. \& Perez-Linan, A. (2002). Assessing the Quality of Democracy: Freedom, Competitiveness and Participation in Eighteen Latin American Countries. Democratization 9(2).

Bawa, I. K. (2013). Legal Constraints to Election Security in Nigeria. In L Olurode (Ed.), Election Security In Nigeria: Matters Arising (31-41). Abuja: Friedrich-Ebert-Stiftung (FES).

Berg-Schlosser, D \& Kersting. N. (2003). Poverty and Democracy: A Contradiction? In D Berg-Schlosser \& N Kersting (Eds.), Poverty and Democracy: Self-Help and Political Participation in Third World Cities. London: Zed Books.

Blais, A \& Dobrzynska, A. (1998). Turnout in electoral democracies. European Journal of Political Research 33.

Bratton, M. (1999). Political Participation in a New Democracy. Institutional Considerations from Zambia. Comparative Political Studies, 32(5).

Cornwall, A. (2002). Making Spaces, Changing Places: Situating Participation in Development. Institute of Development Studies (IDS) Working Paper No 170. Brighton: IDS.

Eze, J. (2019). PDP's Ikpeazu set to be declared winner of Abia governorship election. No Publication Details.

EISA, (2019). Report of the Election Observation Mission on the 2019 General Elections in Nigeria. Abuja: Electoral Institute for Sustainable Democracy in Africa (EISA)

Federal Republic of Nigeria, (2010). Constitution of the Federal Republic of Nigeria (As Amended). The Federal Government Printer, Abuja.

Freitag, M. (2010). Structure versus Culture: A Comparative Study of the Influence of Political Institutions and Cultural Modernization Factors on Voter Turnout in Swiss Sub-national Parliamentary Elections. International Political Science Review, 31(4).

Heywood. A. (1997). Politics. London. Macmillan Press Ltd.

Igini, M. (2013). Election Security in Theory and Practice: Perspective of a Resident Electoral Commissioner. In Lai Olurode (Ed.), Election Security In Nigeria: Matters Arising (43-62). Abuja: Friedrich-EbertStiftung (FES).

ljere, T. C. (2015). Democracy and Development in Nigeria: An Appraisal of the People's Democratic Party (PDP) Sixteen Years. International Journal of Research in Humanities and Social Studies, 2(9), 1-7.

INEC. (2011). Election Manual. The Electoral Institute, INEC, March 2011.

Jega, M. A. (2015). Electoral Reforms in Nigeria: Challenges and Prospects. Paper Presented at the First University of Abuja Public Lecture Series, Thursday October 29, 2015

Jega, M. A. (2012). The Electoral Process and Security Sector Synergy. A Paper Delivered to EIMC 6 Participants of Institute for Security Studies (ISS), Abuja on August 21, 2012.

Jega, A. (2012). Security Challenges Of Election Management: Towards 2015. Keynote Address to The 
Workshop on Election Security. Organized by the Electoral Institute in Conjunction with the Friedrich Ebert Stiftung, at the Transcorp Hilton Hotel, Abuja, August 29th 30th, 2012.

Katuka, Y., Elechi, F. A. \& Ohazuruike, K. (2019). Electoral Bill And Electoral Security In Nigeria: Interrogating The Narratives. International Journal of Social Sciences (IJSS), 3(15), 191-216.

Kuenzi, M. \& Lambright, G. M. S. (2007). Voter Turnout in Africa's Multiparty Regimes. Comparative Political Studies, 40(6).

Lijphart, A. (1997). Unequal participation: democracy's unresolved dilemma. American Political Science Review 91(1).

Mill, J.S. (2011). Considerations on Representative Government. United Kingdom: Parker, Son and Bourn.

NBA, (2019). Election Working Group Report. No Publication Details.

Ojo, O. M. \& Ademowo, J. A. (2015). Electoral Security and Its Implications for Democratic Consolidation in Nigeria. The International Journal of Humanities \& Social Studies, 3(9):5-14

Ojukwu, U. G., Mazi Mbah, C. C. \& Maduekwe, V.C. (2019). Elections and Democratic Consolidation: A Study of 2019 General Elections in Nigeria. Direct Research Journal of Social Science and Educational Studies, 6(4), 53-64.

Olurode, L. (2013). Election Security In Nigeria: Is There A Silver Lining? In L Olurode (Ed.), Election Security In Nigeria: Matters Arising (1-18). Abuja: Friedrich-Ebert-Stiftung (FES).

Olurode, L. \& Hammanga, M. K. (2013). Deployment of Security Personnel in Elections: Challenges and Lessons from the Field. In Lai Olurode (Ed.), Election Security In Nigeria: Matters Arising (63-85). Abuja: Friedrich-Ebert-Stiftung (FES).

Omotola, J S. \& Aiyedogbon, G. (2012). Political Participation and Voter Turnout in Nigeria's 2011 Elections. Journal of African Elections, 11(1), 54-73.

Onwuama, E. M. (2018). Politics and Governance: A Critique of the 2019 Nigeria Presidential Election. International Journal of Academic Research in Public Policy and Governance, 5(1), 50-70.

Partners West Africa, (2018). Nigeria Accountability Brief. Retrieved on September 10, 2018 from: www.partnersnigeria.org.

Sahara Reporters, (2019). DATA: Nigeria's Presidential Election Records Lowest Voter Turnout in 20 Years. Sahara Reporters, New York, Feb 26, 2019

Ugbudian, L. I. (2015). 2015 General Elections In Nigeria: The Role Of Abuja Peace Accord.Department of History and Strategic Studies, Federal University Ndufu-Alike Ikwo, Ebonyi state.

Young, I M. 2000. Inclusion and Democracy. Oxford: Oxford University Press. 